\title{
Gail King
}

"A Model for All Christian Women": Candida Xu, a Chinese Christian Woman of the Seventeenth Century. Collectanea Serica, New Series, 2. Abingdon: Routledge, 2021. Pp. $\mathrm{xv}+162 . \mathrm{Hb}, £ 96 . \mathrm{oo} /$ ebook £ 29.59.

Candida Xu (1607-80) is probably the most famous woman in the history of Chinese Catholicism. A granddaughter of the imperial official and Christian convert Paul Xu Guangqi (1562-1633, baptized 1603), she is famous for her great support of the Jesuit China mission during the last decades of her life. Thanks to a biography written by her confessor, the Jesuit Philippe Couplet, word of her exemplary Christian life and deeds already began to spread in late-seventeenth-century Europe. In the nineteenth and twentieth centuries, Chinese Christian communities, and especially the Shanghai community, also increasingly integrated her into their own remembered past, with several translations of her biography published in Chinese. In her book, Gail King combines Couplet's biography with available Chinese sources, especially the writings by Candida Xu's son Basil Xu Zuanzeng (1627-96?) and the $\mathrm{Xu}$ family records, to present a new and amplified biography of the famous Christian woman. No one could have been more capable to write this book than King, who has studied Candida Xu and her family for almost three decades and is the author of many pertinent articles on the topic.

King's book consists of four chapters that subsequently discuss Candida Xu's ancestors, her childhood and married life, her widowed years, and her legacy. The first chapter is dedicated to the patrilineal lineage of the $\mathrm{Xu}$ family, showing how the family came to settle down in the Shanghai area and how agriculture, commerce, and Confucian learning became the cornerstones of the male family members' activities. The second chapter then turns to Candida Xu's childhood in Shanghai and her married life in Huating in neighboring Songjiang prefecture. King offers a colorful tableau of the local world into which Candida was born, describing Shanghai as a city that, in the early seventeenth century, "retained a rural feeling" (31), where families such as the $\mathrm{Xu}$ family tended to garden plots, raised silkworms, and participated in the local production of cotton weaves (work traditionally done by women). The book also shows how Candida, who was baptized as an infant and raised Christian, experienced her marriage with a non-Christian husband as a disruptive event in her religious life, and how she nevertheless fulfilled the duties of a Confucian wife by raising eight children.

The third chapter focuses on Candida's widowed years, which, according to Confucian social and gender norms, provided her with more freedom and allowed her to expand her pious activities. King recounts Candida's impressive 
support for the Catholic Church during these years. Most notably, Candida provided financial means for many different purposes. For example, she gave money to individual missionaries, for Christian publications, for the creation of new churches, and for a Christian orphanage. Sources state that the wealth that facilitated all this was the result of her own handiwork and business activities. As other researchers have suggested before, King proposes to contextualize these activities in the economic history of Songjiang, which, as a cotton production and trade center, created opportunities for economic success.

The fourth chapter is more essayistic, containing fewer references than the other chapters, but many intriguing thoughts about Candida Xu's place in the history of Chinese Christianity. It shows how Candida's Christian religion never made her oppose Chinese social norms, but instead prompted her to act within Chinese social structures to accomplish her goals. It also shows how her work for the mission, outstanding as it was, was not of lasting impact, as her descendants ceased to be Christians already one or two generations later. An intriguing part of the analysis concerns Candida's rediscovery by missionaries in nineteenth-century China, a topic that invites further study. Three appendices with source translations complement the historical account. Two are translations of texts written by Candida Xu's son Basil, who seems to have been a half-hearted Christian, but as an official serving the newly established Qing dynasty nevertheless helped to realize some of Candida's projects of Christian charity.

The most impressive aspect of King's work concerns her integration of Chinese sources on Candida Xu into her narrative. Sources such as the Xu family records and Basil Xu Zuanzeng's autobiographical preface to his "Baolun tang gao," both unpublished manuscripts held by Chinese libraries, allow her to add new details to the story of the Xu family and of Candida's life, including exact life dates of $\mathrm{Xu}$ family members and valuable information on marriage relations. This is an important complement to European sources written by missionaries, which usually pay much less attention to such information. The book thus succeeds in adding important details to the historical framework of Candida Xu's biography.

As concerns the interpretation of her sources, King remains very close to the interpretations offered by the historical texts themselves. Little reflection is paid to questions of genre, which could have helped to clarify some of the discursive contexts in which the sources on Candida $\mathrm{Xu}$ need to be placed. Although King stresses in her introduction that Couplet's biography aimed at evangelism and therefore "emphasized faith that led to good works" (10), she refrains from reading this text in the context of early modern "spiritual vitae," a genre that followed a set of rules when exalting religious virtue. In the same 
vein, the normative Confucian framework into which the Xu family writings were embedded is not reflected upon in the text. It is true that "awareness that the biography was written with a purpose does not mean that the whole story is a fiction" (12). However, embedding the sources into their discursive contexts would have helped to develop a greater awareness towards certain textual tropes such as Confucian generosity (18) or Christian prayerfulness (64) and thus towards the insecurities that remain in the interpretation of the available sources on Candida Xu. Even so, Gail King's biography of Candida Xu is a valuable addition to the scholarship on early modern Chinese Christian women and to the study of the Xu family. It not only recounts the life of an exemplary Chinese Christian woman, but also provides many details on a prominent Chinese Christian family.

\section{Nadine Amsler}

Wissenschaftskolleg zu Berlin, Berlin, Germany

nadine.amsler@wiko-berlin.de

DOI:10.1163/22141332-08040011-08

\section{Eric Verbiest}

God of de Keizer?: Pater Ferdinand Verbiest in China. Gompel \& Scavina: Antwerp, 2020. Pp. 290. Pb, €34.00.

Eric Verbiest's God of de Keizer? is an enticing narrative of the Jesuit China missions from the 1630 os until the late 168 os that focuses on Ferdinand Verbiest's accomplishments in order to analyze the Jesuit approach Verbiest came to embody: was it possible to convert the emperor (and the rest of China) by offering and illustrating the usefulness of Western scientific, mathematical, and astronomical knowledge? God of de Keizer? is organized in ten mostly chronological chapters, which are further subdivided into two- to six-page-long fragments, formatted as Jesuit letters or Chinese and Manchu daily reports. This set-up makes for an engaging and fast-moving read, whereby the reader is drawn into a constantly evolving first-person chronicle.

The story starts with shipwrecks and pirate attacks, diseases, and altercations with the Dutch East India Company. While this part may not yet dig deep into the Jesuit type of accommodation they established in China-in particular the dilemma of serving God or the emperor-Eric Verbiest reminds the readers of the dramatic parameters of Jesuits' global lives. That is not to say that there was any less drama more regionally, during the dynastic transition from Ming to Qing — the setting of chapter two. This comes out most viscerally 